\title{
LEGAL INTERVENTION IN PLANNING REGU- LATIONS: COOPER V WANDSWORTH IN A WEST AFRICAN CONTEXT.
}

\author{
Kwadwo B. MENSAH \\ Department of Economics and Business Studies \\ University of Cape-Coast \\ CAPE-COAST \\ GHANA
}

\section{SUMMARY}

One of the most important problems facing many West African cities in recent times is rapid and seemingly uncontrollable urbanization ${ }^{1}$. The enormous pressure which these developments have had on public systems in general - sanitation, sewage, housing, health care and transport, has forced many cities to think of innovative ways of handling these crisis. Planning departments with substantial expertise in urban problems, are being set up or are being re-organized to meet these new challenges. The powers that planning departments have, and their impact on the lives of ordinary citizens cannot be over-estimated. To prevent abuse of power and to make them responsive to the needs of citizens, several methods are used to control them. Judicial review of administrative actions is the legal method used to control many public bodies in English speaking West African countries.

In this article, I shall argue that in spite of its strengths, there is a general tendency to use judicial review to protect common law values like individual proprietary rights against the claims of state institutions. In West Africa, because of the 
weakness of public institutions, the intervention of the law, while protecting important private rights may hamper administrative effectiveness. Anticipating the use of the leading English case, Cooper $v$ Wandsworth ${ }^{2}$ in reviewing planning decisions in West Africa, I shall conclude that such a position may not only diminish administrative effectiveness, but it may also diminish property rights.

KEY WORDS: Planning, Administrative Effectiveness, Common Law in West Africa, Cooper v Wandsworth, Statutory Interpretation.

\section{The Advantages and Disadvantages of Legal Intervention.}

The aim of judicial review is to ensure that public institutions remain within their jurisdictions, obey the law and do not abuse individual rights ${ }^{3}$. There are obvious strengths in legal review of administrative action. Adjudication provides an impartial forum for resolving disputes ${ }^{4}$. The English legal view, that the state and the individual appear in court as equals, subject to the same rights and constraints ${ }^{5}$, may give the citizen greater confidence in this method of dispute resolution.

However, there are also acknowledgements that there are inherent weaknesses in judicial review, and this can make it unsuitable for dealing with issues in the public domain. First, there are differences as to what is good decision making from administrative and legal perspectives. The common law has a tendency to view issues from the individual's point of view and seeks to promote individual rights against the claims of the state ${ }^{6}$. Disputes are likely to be resolved without looking at the implications for the society in general. ${ }^{7}$ Finally, the common law's determination to do substantive justice in each case can make litigation slow and expensive.

Administrative effectiveness can also be hampered if legal values are given precedence over administrative concerns. The courts have no expertise in the substantive administrative decisions which they review, and this is particularly important when it comes to dealing with discretionary powers ${ }^{8}$. The law tends to see decision-making in the public sphere as 'single, discrete and unproblematic as opposed to complex, subtle and woven into a broader process"' 
More fundamentally, it has been argued that there has been significant changes in the nature of modern societies which has resulted in a shift from the regime of private law, which is concerned mainly with protecting individual rights - a situation where the common law is most effective -, to a more public law regime which is concerned with welfare and social utility ${ }^{10}$. Consequently while the merits of an individual case is bound to play a role in decisions made by state bureaucracies, the primary objective of bureaucratic decision-making is to lay down procedures through which 'mass adjudication' can take place. Bureaucracies look directly at the effect a decision would have on the society in general ${ }^{11}$.

The use of judicial review as a means of controlling administrative action in 'commonwealth' West Africa can lead to even greater difficulties. There is a tendency for African courts to apply English cases without examining critically the circumstances in which a case was decided. They also fail to understand the values which the common law seeks to protect and whether these values cohere with our present aspirations. Taking the problems that bureaucracies face in Africa, the application of English law to correct 'maladministration', may in fact worsen already bad situations. The application of English cases can lead to the imposition and protection of values which may not be in consonance with the dominant values and aspirations of a modern developing society.

The need for the courts and bureaucracies to resolve these tensions properly, has become even more acute because of the radical changes in thinking about the role of the state in Africa's political economy. It is now generally accepted that there are limits to the extent that the state can intervene directly in the economy. Some have argued that the market economy can deal better with the problems of economic organization and development. The need to promote private enterprise is likely to bring with it various ideologies that champion the protection of individual liberty and private property. It is not unlikely that the biases of the common law will be called upon to defend private property even when this is not in the interest of society at large. This is what is likely to happen when decisions of planning departments are challenged in court. 


\section{The Problem}

We have already indicated that one of the most difficult problems facing African cities is uncontrollable urbanization. Governments have been unable to provide enough housing to the rapidly increasing urban population. Consequently adequate housing is in short supply and is very expensive. The private sector is now leading the drive to solve these problems. Unfortunately, planning departments have been unable to keep up with the pace of urban development. As a result most private developers build without any planning regulations or just ignore them when they exist. It is not uncommon to find private housing development taking place in an industrial area. Squatter settlements are now a major part of every major West African city. Areas are developed without the provision of social amenities. Even when developers are given clear warnings to stop developing an area, they ignore these warnings. Their hope is that, presented with a fait accompli, there is very little municipal governments, burdened with other problems, can do.

But there are obvious dangers in ignoring planning regulations. The lack of social amenities has direct effects on public health. Inadequate sanitation promotes epidemics like typhoid, cholera malaria and tuberculosis. The menacing return of malaria can be attributed directly to the failure of city planners to provide proper infrastructure to deal with sanitation. Bad sewage systems have negative impacts on the environment. Lack of adequate communication encourages crime. The consequences of ignoring planning regulations are general and municipal governments cannot ignore them.

So what is likely to happen if a municipal authority demolishes a house in an area, where the developer has ignored planning regulations? If the developer goes to court for judicial review of the decision, it is not unlikely that his counsel may rely on the famous English case of Cooper $\mathrm{v}$ Wandsworth ${ }^{12}$.

In Cooper v Wandsworth, we see clearly, the resolution of the tensions between the common law and bureaucratic values in favour of the common law. A hierarchy of values are displayed in which property rights are given precedence over administrative effectiveness. Applied in West Africa, it is bound to make the implementation of planning regulations very difficult ${ }^{13}$. 


\section{Background to Cooper v Wandsworth.}

To understand why the biases of the common law was used to protect property rights at the expense of other values in Cooper $v$ Wandsworth, we must look at the nature of English society at the time the case was decided.

The second part of the nineteenth century was a period of steady industrialization and urbanization in England. Many people left the rural areas to the urban centers in search of work. This led to large increases in the urban population. With increasing industrialization and urbanization, the probability of outbreaks of contagious diseases could not be under-estimated. Land use planning was essential for controlling diseases, especially the ones that came through the drainage system. Local authorities were given the responsibility to develop adequate planning regulations to prevent the spread of diseases ${ }^{14}$.

Section 76 of the Metropolis Local Management Act 1855. (18 \& 19, Vict. c. $120)^{15}$, was an act meant to regulate land use. It contained regulations about how to construct buildings. It also provided detailed instructions on how drains should be laid. The statute gave district boards discretion to alter or demolish any structure, if the builder failed to give seven days notice of an intention to build.

The need to protect public health however, had to be achieved within a framework of the norms valued in a society based mainly on private property. Private property is one of the most important institutions in the political economy of English society. Consequently it had to be given reasonable protection. Failure to do this would have weakened the economic base of the society. The seven days notice requirement was thus a mechanism through which two different but not necessarily opposing interests - public health and property - could be integrated. Providing the board with notice of an intention to build, gave the board the opportunity to examine the plans of the building, e.g. the drainage system etc, in order to ensure that the structure conformed to accepted standards. Thus an owner's right to enjoy his property was not made at society's expense. 


\section{Interpreting the Regulations.}

There are various ways a statute can be interpreted. In connection with Section 76 of the Metropolis Local Management Act 1855. (18 \& 19, Vict. c. 120, two possible interpretations are noted here. The first position, - which we shall call the conservative interpretation - makes a distinction between substantive and merely procedurally issues. Substantive issues are more important than procedural ones. The substantive aim of the statute, from this perspective, is to protect private property in the course of promoting public health. The seven days notice requirement is merely a procedure through which the substantial objective can be achieved.

A point which the conservative interpretation is likely to emphasize relates to the consequence of a failure to give notice of an intention to build. Giving notice of an intention to build only allows the district board the opportunity to ensure that the public health regulations have been complied with. Failure to inform the district board however, does not imply that a building does not meet the public health regulations.

Another way to interpret the regulations, - which we shall call the neutral interpretation - looks at the particular circumstances to determine what has to be done to protect public health. The hierarchy in which property rights are always more important than administrative effectiveness is rejected. Property rights and administrative effectiveness have equal value.

\section{Cooper v Wandsworth.}

A house which the plaintiff was building was demolished by the board because he failed to comply with the notice requirement. The plaintiff brought an action of trespass against the defendants. Basing his argument on the conservative position, he claimed that the health board had exercised its discretion improperly. The plaintiff argued that before his house could be demolished, the board had to give him an opportunity to be heard. 
Erle C.J. accepted the conservative argument on appeal. We must look closely at the reasons for his position, especially the way he interprets the purposes of the statute in order to defend a conservative interpretation of the statute. Erle C.J. states that

"The contention on the part of the plaintiff has been that although the words of statute, taken in the literal sense, without any qualification at all, would create a justification for the act which the district board has done, the powers granted by that statute are subject to the qualification which has been repeatedly recognized that no man is to be deprived of his property without having an opportunity of being heard." 16

According to him, wide and somewhat arbitrary powers would be available to the district board, if the court accepted the defendant's argument. While these powers will still be open to review, legal control will be limited only to examining whether procedural conditions had been satisfied. There will be nothing to ensure that substantive issues had been dealt with before a house is demolished. Thus the district board would have authority to demolish any property, whatever its costs, if the builder merely failed to meet the procedural conditions.

The consequences for property owners and society could be very disastrous. Inter-linking arguments about the need to satisfy the requirements of local democracy, i.e. the need to keep public bodies in check and the right to participate in decision making is made by Erle C.J.

"It is a power carrying with it enormous consequences. The house in question was built only to a certain extent. But the power claimed would have applied to a complete house. It would apply to a house of any value, and completed to any extent; and it seems to me to be a power which may be exercised most perniciously, and that the limitations which we are going to put upon it, is one which is required by a due consideration of the public interest. "17

We must note the way in which he promotes the interest of property owners at the expense of the duties of the district board. He argues that the power to demolish a building is given for a purpose. The board's argument fails to make the distinction between the substantive and the procedural aspects of the statute. The incoherence of their position is seen if we look at the consequences of their argument. It amounts to a claim that even if a house meets the public health regulations, it 
can demolished, if the builder has not given notice of his intention to build. This amounts to valuing process over substance.

However the district board would find out if the public health regulations have been met if they gave the builder a hearing. A hearing also has the added advantage of enhancing proper decision making.

"I think the board ought to have given notice to the plaintiff, and to have allowed him to be heard. The default in sending notice of the intention to build is a default which may be explained. There may be a great many excuses for the apparent default. The party may have intended to conform to the law. He may have actually conformed to all the regulations which they wish to impose, though by accident his notice may have miscarried; and, under those circumstances, if he explained how it stood, the proceeding to demolish, merely because they had ill-will against the party, is a power that the legislature never intended to confer. I cannot conceive any harm that could happen to the district board from hearing the party before they subjected him to a loss so serious as the demolition of his house; but I can conceive a great many advantages which might arise in the way of public order, in the way of fulfilling the purposes of the statute, by the restriction which we have put upon them. ${ }^{118}$

\section{Criticisms of Cooper $\mathbf{v}$ Wandsworth.}

The are two weaknesses in Erle C. J.'s reasoning. First, his adherence to the conservative interpretation prevents him from looking for other plausible interpretations of the regulations, e.g. the neutral interpretation, which would allow him to address the concerns of the district board. The board would be interested primarily in creating procedures which would help it to protect public health quickly and cheaply. The burden of added costs which hearings will have on the district public health board's budget is not taken into consideration. Erle C.J. also fails to consider the consequences for public health due to delays caused by hearings.

From a conservative point of view, the need to protect individual property rights seems overwhelming. Issues of costs and bureaucratic effectiveness are ignored or are given secondary importance. From a conservative/ legal point of view, it may seem harsh if not downright foolish to demolish a house if the builder 
has merely failed to give notice of an intention to build. From and administrative point of view however, it may make a lot of sense. It will be cheaper and administratively more effective to insist rigidly on the notice requirement. Then the need for and the cost of hearings would be reduced substantially. Demolishing a completed house will probably be the best warning that the planning department can give to developers about the importance they attach to planning regulations. The temptation on the part of a developer to commence work, knowing that the courts will require a hearing after he has began, would be substantially curtailed.

The second weakness of the decision in Cooper $\mathrm{v}$ Wandsworth is even more fundamental. It fails to establish the connection between the protection of private property and the rationale for the institution of private property. While in Cooper v Wandsworth, property rights are significantly protected, we are not given a rationale for their protection. It is left hanging in the air without any intellectual support. The result is that while Cooper v Wandsworth seems to be an attempt to protect property rights, a critical look at its consequences is that it may in fact end up undermining property rights.

It is important here to provide a justification for the institution of private property and see how this justification coheres with the decision in Cooper $v$ Wandsworth. Finnis has argued very succinctly, that there are two types of values - basic and non basic values - in the lives of humankind ${ }^{19}$. Knowledge for example is a basic value because it is an end in itself. Property on the other hand has only instrumental value because it is only a means of achieving the more basic values ${ }^{20}$. Through the institution of private property, individual autonomy can be advanced and the common stock of nature managed efficiently ${ }^{21}$.

Yet in spite of its importance in the affairs of humankind, Finnis acknowledges that there are limitations to the efficacy of private property. He argues that no society can flourish securely unless there is effective collaboration within it to exploit the common stock of nature. As societies become more advanced, collaboration beyond the point of protecting private property, becomes even more necessary, if individual autonomy is to be enhanced and societal resources managed more efficiently. To achieve this, a body with a public character has to be set up, charged with the responsibility of making the rules that distribute the burdens and advantages of collaboration ${ }^{22}$. Sometimes such public bodies must be given unreviewable discretion in order to make them effective. Thus while private property helps to promote autonomy and efficiency, it is always the case that it has to be supplemented by state intervention in order to achieve the objectives of autonomy and efficiency. 
Unfortunately, the complexities of the relationship between the institution of private property, the protection and promotion of individual rights, the efficient exploitation of natural resources and the role that public bodies have to play to achieve these objectives are not examined by Erle C.J.. He is quick to assume that private property has overwhelming importance and is thus very eager to protect it. He does not address the possibility that the procedures of the planning departments actually promote the institution of private property by making them more secure. After all what is the importance of property, if planning departments cannot check the spread of contagious diseases because they cannot intervene into private property rights to prevent the development of insanitary conditions?

\section{Application of Cooper v Wandsworth in West Africa.}

Whatever its merits, there is one reason why, when it comes to planning, Cooper v Wandsworth should not be applied in West Africa. First, generally, government departments in West Africa are notoriously weak because of under-funding. Consequently, they are not even able to deal with the basic problems which they have been created to solve. As we have already noted, planning departments have been unable to keep up with the pace of urban development. To add the requirement of a hearing before a structure which has failed to adhere to planning requirements is demolished, would be to put a heavy burden on such departments. In fact, they are almost certain to ground to a halt. In societies which have never taking planning regulations seriously, developers must be made aware, in very dramatic forms, the consequences of ignoring planning regulations. Legal intervention, if it has to take place must promote adherence to planning regulations, instead of the rigid protection of property rights.

This position is further accentuated by the way housing development is organized in West Africa. In West Africa, houses are normally built by individuals. In western countries, development is done mainly by large development companies constructing similar types of structures. Consequently, in Europe, for example, even if a developer ignores planning regulations, public health requirements can be examined at the hearing stage by looking at the company's development plans. This procedure is not likely to be of any use in West Africa because individuals build according to their own desires and in ways which may not fit into the plans laid by the planning department. If planning regulations are to be satisfied, each developer who ignores planning regulations has to be given a hearing. This will 
be very slow and will make enforcing planning regulations extremely expensive for planning departments.

\section{The Way Forward.}

Generally, West Africans have a lot of catching up to do in the area of respecting and adhering to planning regulations. In order to achieve this important objective, several things have to be done.

The importance of planning regulations must be made known to all. Public education is extremely vital. While people are becoming aware of the dangers of environmental degradation, few know that planning departments have been set up to promote efficient land use. In fact most people in West Africa think that they can do whatever they want to do with their lands. If people become aware that planning regulations protect the environment and their properties, they are more likely to obey them. The connection between efficient land use and individual autonomy, must be incorporated into public education.

Secondly, planning regulations must also be made simple enough for ordinary developers to understand. The more complex the regulations, the more difficult it will be for developers to follow them, and the more likely it is that they will be ignored.

Thirdly, planning departments must have long term development plans into which individual plans can be situated. They must be able to anticipate the extent of population growth and the rate of increase in urbanization. Then they should zone out areas, with clear plans as to what a particular area is intended for. Through the use of restrictive covenants, land owners should be made to adhere to the planning regulations in the development plan. It is the failure to anticipate the rate of urban growth and therefore to construct realistic development plans that has caused many developers to build without taking the impact of their activities on the environment into consideration.

Fourthly, planning department must be given power to enforce planning regulations and this is where the character of legal intervention is important. Planning departments should be encouraged to use these powers to prevent non-adherence to planning regulations. In countries where there has not been a long history 
of deliberate city planning, this may perhaps be the most important task. People may not easily recognize the importance of planning and are likely to resist any attempt to interfere with their land use rights. Governments must consequently give planning departments real legal and political backing to enforce their regulations.

All these suggestions are meant to make planning departments more effective. The law must now take issues relating to bureaucratic effectiveness very seriously. Common law principles must not be used to promote individual rights at the expense of good administration. 


\section{NOTES}

1. O'Connor A., The African City, Hutchinson, 1983.

2. 143 English Reports, Common Pleas, 414 - 421.

3. Craig, P.P., Administrative Law, Sweet and Maxwell, 1989.

4. Fuller, L., 'The Forms and Limits of Adjudication', [1976-7] 92, Harvard Law Review, pp. 353-409.

5. Wade, H. W. R., Administrative Law, (sixth edition), p. 22.

6. Allan T. R. S. 'The Limits of Parliamentary Sovereignty' [1895], Public Law, pp. 614-636. Allan, T. R. S., 'Legislative Supremacy and the Rule of Law', [1985] 44 Cambridge Law Journal, pp. 111-143.

7. Atiyah, P. S., Pragmatism and Theory in English Law, London, Stevens and Sons, 1987.

8.. Williams, D. G. T., 'Justiciability and the Control of Discretionary Powers', in Judicial Review of Administrative Action in the 1980s, (ed) M. Taggart, pp. 103-122.

9. Baldwin R., and Hawkins K., 'Discretionary Justice: Davis Reconsidered' [1984], Public Law, p. 580.

10. Kamenka E. and A. Erh-Soon Tay, 'Beyond Bourgeois Individualism: the Contemporary Crisis in Law and Legal Ideology', in Feudalism, Capitalism and Beyond, (ed) E. Kamenka and R. Neale, pp. 127-130.

11. Arthurs H. W. 'Rethinking Administrative Law: A Slightly Dicey Business' [1979], 17, Osgoode Hall Law Journal, pp. 1-45; see also Titmuss, R. M., "Welfare Rights", Law and Discretion', Political Quarterly [1971] pp. 113-132; M. Bouchard., 'Administrative Law in the Real World: A View From Canada', in Judicial Review of Administrative Action in the 1980s, (ed) by M. Taggart. pp. 179-198.

12. 143 English Reports, Common Pleas, pp. $414-421$.

13. The overwhelming approval with which Cooper $v$ Wandsworth has been received in English legal commentaries has been due mainly because it is seen as case involving issues of natural justice alone. However, if one views that case as involving the use of discretionary powers-discretion to decide what administrative procedures should be implemented to make planning decisions more effective, one is not unlikely to see it as such a good decision.

14. For a historical explanation of these issues see Waller, P. J., Town, Country and Nation, England 1850-1910; W.M. Fraser, A History of English Public Health, 18391939. 
15. 143 English Reports, Common Pleas, 414.

16. 143 English Reports, Common Pleas 417.

17. ibid.

18. ibid $417-418$.

19. Finnis J., Natural Law and Natural Rights, Clarendon, 1980, chapters 3 \& 4.

20. ibid 168-171.

21. ibid

22. ibid 168 . 